\title{
JURNAL GERIA
}

ISSN : 2614-6347 (Print) 2714-4107 (Online)

Vol.1 | No.5 | September 2018

\section{PERMAINAN KANCING UNTUK PENINGKATAN PERKEMBANGAN KETERAMPILAN FISIK-MOTORIK ANAK USIA DINI}

\author{
Clara Siti Sendari ${ }^{1}$, Iin Indriani ${ }^{2}$, Arifah A Riyanto ${ }^{3}$, Dedah Jumiatin ${ }^{4}$ \\ ${ }^{1}$ PP Kemuning, Cimahi. \\ ${ }^{2}$ Daycare Hati Bunda, Cimahi. \\ ${ }^{3}$ Institut Keguruan dan Ilmu Pendidikan (IKIP) Siliwangi, Cimahi. \\ ${ }^{4}$ Institut Keguruan dan Ilmu Pendidikan (IKIP) Siliwangi, Cimahi. \\ 1․arasendari@gmail.com, ${ }^{2}$ dadanpriatna889@gmail.com, ${ }^{3}$ arifahastim@yahoo.com \\ 4dedahcimahi@yahoo.com
}

\begin{abstract}
Abstrak
Salah satu aspek perkembangan fisik-motorik pada anak usia dini adalah otot-otot yang mempengaruhi perkembangan kekuatan dan kemampuan motorik (kasar dan halus) yang dapat ditingkatkan melalui aktifitas pembelajaran atau kegiatan permainan yang variatif, kreatif, dan menyenangkan sesuai dengan karakter anak yang aktif, dinamis dan antusias. Permainan kancing merupakan kegiatan bermain menggunakan media kancing yang memiliki beragam bentuk, warna, dan ukuran, yang dilakukan atau dikemas dalam bermacam cara atau strategi, antara lain memasukkan kancing kedalam botol, meronce, menyambung pita, memasangkan kancing sesuai bentuk dan warnanya, memindahkan kancing menggunakan pinset, yang dilakukan dengan berjalan atau berlari. Penelitian tindakan yang dilakukan di kelas ini bertujuan mengetahui peningkatan perkembangan keterampilan fisik-motorik anak melalui pendekatan permainan kancing yang dilaksanakan dalam dua siklus. Teknik yang digunakan dalam pengumpulan data melalui pedoman penilaian dan lembar observasi. Data diperoleh dari hasil penelitian menggunakan metode analisis statistik dan analisis deskripsi. Penelitian dilakukan terhadap 15 anak berusia dini. Data hasil dari penelitian dan analisis menunjukkan terjadi peningkatan perkembangan keterampilan fisik-motorik pada anak sebagai subjek dari penelitian. Ini menunjukkan bahwa permainan kancing dapat meningkatkan perkembangan keterampilan fisik-motorik pada kelompok anak usia dini.
\end{abstract}

Kata Kunci: permainan kancing, peningkatan, perkembangan motorik

\begin{abstract}
One aspect of physical-motor development in early childhood is the muscles that affect the development of strength and motor skills (rough and smooth) which can be increased through learning activities or play activities that are varied, creative, and fun in accordance with the character of an active child, dynamic and enthusiastic. Button play is an activity of playing using button media that has a variety of shapes, colors and sizes, which are carried out or packaged in various ways or strategies, including inserting buttons into bottles, rooting, connecting ribbons, attaching buttons according to their shape and color, moving buttons using tweezers, which is done by walking or running. The action research conducted in this class aims to find out the improvement of the child's physical-motor skills development through the button game approach which is carried out in two cycles. The technique used in data collection is through assessment guidelines and observation sheets. Data obtained from the results of research using statistical analysis methods and description analysis. The study was conducted on 15 children at an early age. Data from the results of research and analysis showed an increase in the development of physical-motor skills in children as subjects of the study. This
\end{abstract}




\section{JURNAL GERIA}

ISSN : 2614-6347 (Print) 2714-4107 (Online)

Vol.1 | No.5 | September 2018

shows that the button game can improve the development of physical-motor skills in the early childhood group.

Keywords: button game, enhancement, motor development 


\section{PENDAHULUAN}

Hakekat anak usia dini yang terdapat dalam Undang-Undang Sistem Pendidikan Nasional No 20 Tahun 2003 adalah kelompok manusia yang berusia 0 sampai dengan 6 tahun. Tetapi beberapa ahli berpendapat dan mengelompokkannya sampai usia 8 tahun (Essa dalam Mutiah, Diana. 2010).

Anak usia dini adalah kelompok individu yang termasuk pada usia pra sekolah, berada pada masa dimana terjadi suatu proses perubahan dalam pertumbuhan juga perkembangan yang sangat pesat pada aspek fisik (jasmani) maupun psikis (rohaninya), serta proses kematangan dan penyempurnaan. Proses perubahan itu berlangsung secara bertahap dan berkelanjutan. Masa ini bahkan dapat dikatakan juga sebagai lompatan perkembangan.

Usia Dini dikatakan juga sebagai masa emas (golden age), usia yang sangat istimewa, dan sangat berharga, dibanding dengan usia-usia selanjutnya. Usia yang merupakan urutan atau fase atau tahap kehidupan yang unik karena berada dalam tahap proses pertumbuhan dan perkembangan yang unik, artinya memiliki pola pertumbuhan dan perkembangan dalam koordinasi antara motorik kasar dan halus (aspek fisikmotorik), daya pikir dan daya cipta (aspek kecerdasan), aspek sosio emosional, serta aspek bahasa dan komunikasi yang sangat pesat. (Isjoni, H.. 2014.)

Anak usia dini selalu bergerak aktif dan dinamis, sangat antusias, memiliki sifat menomorsatukan diri sendiri atau egosentris, selalu ingin tahu yang muncul secara alamiah terhadap segala sesuatu yang dilihat dan didengarnya, juga merupakan makhluk sosial atau individu yang sangat bergantung pada bantuan orang lain, unik, suka berimajinasi dan berfantasi, serta memiliki kemampuan perhatian dan daya konsentrasi yang pendek. Masa ini adalah merupakan saat atau waktu yang sangat potensial untuk belajar, peletak dasar dalam keberhasilannya kelak di usia dewasa, peletak dasar dalam perkembangan fisik atau jasmani, kognitif atau pengetahuan, bahasa, emosi, kepribadian, sosial, dan spiritualnya.

Perkembangan keterampilan fisikmotorik anak dalam hal koordinasi antara motorik kasar dan motorik halus dapat terkoordinasi dengan baik sejalan dengan kematangan perkembangan fisik. Penggunaan mata dan tangan sudah dapat terkoordinasi dengan baik. Anak semakin mampu mengurus dirinya sendiri dengan sedikit pengawasan orang dewasa. Dengan kemampuannya ia mulai dapat memegang dan menyikat giginya, menggunakan sisir untuk menyisir rambutnya, mengenakan dan mengancingkan pakaiannya, membuka dan menutup ritsluiting, mengenakan sepatu pada kakinya sendiri, serta makan sendiri dengan menggunakan sendok dan garpu, mulai dapat mengggunakan tangannya untuk membuat karya seni atau berkreasi. Misalnya, menggunting kertas, membuat gambar walaupun masih sederhana dan mewarnainya, menggunakan klip, menjahit, menganyam kertas, serta menggunakan rautan pensil untuk menajamkan pensil.

Berdasarkan pemaparan diatas, maka penelitian tindakan yang dilakukan di kelas dengan judul "Permainan Kancing Untuk Peningkatan Keterampilan FisikMotorik Anak Usia Dini”, dipilih sebagai salah satu langkah atau pendekatan untuk memotivasi dan menstimulus anak-anak dengan menciptakan suasana menyenangkan dan variatif, sehingga anak-anak dapat bersemangat dan antusias mengikuti proses belajar-mengajar melalui permainan untuk mencapai perkembangan keterampilan fisikmotorik yang optimal sesuai pola 
perkembangan dan karakter masingmasing.

Perumusan masalah yang dirumuskan oleh peneliti dalam penelitian yang dilakukan di kelas ini adalah "Apakah melalui permainan kancing dapat meningkatkan keterampilan fisik-motorik anak usia dini?"

Adapun tujuan penelitian ini, yaitu: mendapatkan gambaran tentang penerapan pendekatan permainan kancing untuk peningkatan perkembangan keterampilan fisikmotorik anak usia dini.

Dengan data-data yang didapat maka guru dan orang tua dapat membuat rencana proses kegiatan belajar mengajar untuk anak usia dini melalui permainan kancing untuk memotivasi dan menstimulus anak-anak dalam meningkatkan perkembangan keterampilan fisik motorik secara optimal sesuai pola perkembangan dan karakter masing-masing agar anak semakin mampu menolong dirinya sendiri dan semakin dapat bertanggung jawab.

Menurut Santrock permainan adalah suatu aktifitas untuk mencari kesenangan atau suatu kegiatan yang menyenangkan, yang dilakukan atau dilaksanakan untuk kepentingan kegiatan itu sendiri. Permainan memberi kesempatan anak untuk dapat menyalurkan energi fisik yang berlebih dan membebaskan atau melepaskan perasaan yang terpendam. Dengan bermain ini perasaan anak akan menjadi bahagia, sehingga akan mengalami kenyamanan dalam melakukan serangkaian kegiatan pembelajaran. (Fadlillah, 2014)

\section{METODOLOGI PENELITIAN}

Dalam pelaksanaannya, penelitian ini menggunakan bentuk metode penelitian tindakan kelas (PTK), yang mengacu pada teori Mc. Taggart (Heris, 2014: 40) yang menyatakan bahwa penelitian dalam bentuk tindakan kelas adalah studi yang dilakukan untuk dapat melakukan perbaikan diri sendiri dalam berbagai aspek, juga memberikan pengalaman pada anak untuk dapat bekerja sendiri, yang dilakukan secara sistematis atau bertahap, terencana, dan dengan sikap mawas diri. Adapun prosedur atau langkah-langkah pelaksanaan penelitian tindakan kelas ini mencakup: (1)Menentukan fokus masalah penelitian. (2)Menyusun rancangan tindakan (Perencanaan). (3)Pelaksanaan tindakan. (4)Pengamatan (observasi). (5)Refleksi (pantulan)

Penelitian ini dilaksanakan mulai tanggal 23 Juli 2018 sampai dengan tanggal 16 Agustus 2018. Partisipan dalam proses pelaksanaan penelitian ini adalah peneliti, guru kelas dan anak kelompok usia 5-6 tahun di Kelompok B yang berjumlah 15 anak terdiri dari 9 laki-laki dan 6 perempuan sebagai subjek penelitian. Penelitian ini dilakukan dengan tujuan untuk mendapatkan suatu gambaran tentang penerapan pendekatan permainan kancing untuk meningkatkan perkembangan keterampilan fisikmotorik pada anak usia 5-6 tahun yang dilaksanakan melalui empat tahap. Tahap pertama adalah perencanaan. Tahap kedua adalah pelaksanaan. Tahap ketiga adalah observasi dan evaluasi. Tahap yang keempat adalah analisis dan refleksi.

Adapun teknik yang digunakan dalam pengumpulan data ataupun informasi lainnya dalam penelitian ini adalah teknik Observasi dan Dokumentasi. Menurut Creswell (2014:261), dalam penelitian yang dilakukan, peneliti itu sendiri sebagai instrumen penelitian, yang mengumpulkan sendiri data dengan dokumentasi dan observasi perilaku yang diamati. Dalam penelitian ini untuk meng-analisis data menggunakan pendekatan analisis kualitatif dengan model interatif. Miles dan Huberman 
(dalam Hopkins, 2011: 237), hal penting dalam penelitian tindakan kelas adalah validitas data.

\section{HASIL DAN PEMBAHASAN Hasil}

Permainan kancing ini dikemas dalam beberapa kegiatan, yaitu meronce, memasangkan kancing sesuai bentuk dan warnanya, menyambung pita, memasukkan kancing ke dalam botol sesuai warna sambil berlari, memindahkan kancing menggunakan pinset sambil berjalan.

Pada penelitian pra siklus, keterampilan fisik-motorik (koordinasi motorik kasar dan halus) anak masih belum berkembang terlihat dari rata-rata pencapaian keterampilan fisik-motorik anak dalam menyelesaikan tugas meronce mencapai score 19 (31,67\%); memasangkan kancing sesuai bentuk dan warnanya rata-rata mencapai score 25 (41,67\%); menyambung pita rata-rata mencapai score $20 \quad(33,33 \%)$; memasukkan kancing ke dalam botol sesuai warna sambil berlari rata-rata mencapai score $25 \quad(41,67 \%)$; memindahkan kancing menggunakan pinset sambil berjalan rata-rata mencapai score $22(36,67 \%)$.

Penerapan permainan kancing pada proses tindakan atau siklus I keterampilan fisik-motorik pada anak yang diobservasi mengalami peningkatan, meronce rata-rata mencapai score $31 \quad(51,67 \%)$; memasangkan kancing sesuai bentuk dan warnanya rata-rata mencapai score 42 (70\%); menyambung pita rata-rata mencapai score 39 (65\%); memasukkan kancing kedalam botol sesuai warna sambil berlari rata-rata mencapai score 43 (71,67\%); memindahkan kancing menggunakan pinset sambil berjalan rata-rata mencapai score 41 (68,33\%).

Pada siklus II, meronce mencapai score $44 \quad(73,33 \%)$; memasangkan kancing sesuai bentuk dan warnanya rata-rata mencapai score $45 \quad(75 \%)$; menyambung pita rata-rata mencapai score $44 \quad(73,33 \%) ; \quad$ memasukkan kancing kedalam botol sesuai warna sambil berlari rata-rata mencapai score 46 (76,67\%); memindahkan kancing dengan menggunakan pinset sambil berjalan rata-rata mencapai score 47 $(78,33 \%)$.

Peningkatan Keterampilan Fisik Motorik Pra Siklus, Siklus I, Siklus II tampak pada grafik di bawah ini:

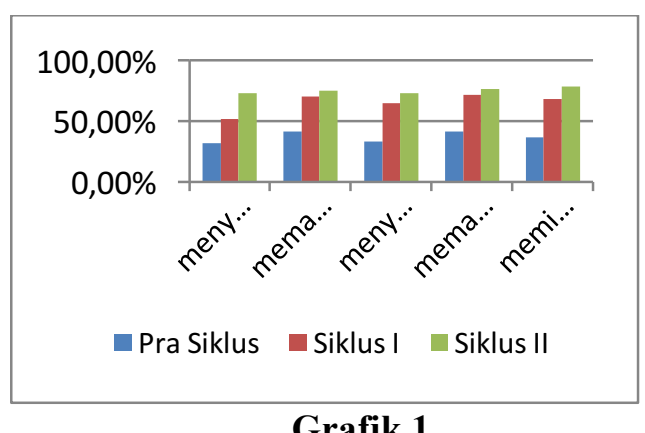

Peningkatan Keterampilan Fisik Motorik Pra Siklus, Siklus I, Siklus II

\section{Pembahasan}

Berdasarkan hasil yang tampak pada grafik sebagai hasil dari penelitian yang telah dilakukan menunjukkan bahwa permainan kancing yang dikemas dalam kegiatan meronce, memasangkan kancing sesuai bentuk dan warnanya, menyambung pita, memasukkan kancing ke dalam botol sesuai warna sambil berlari, memindahkan kancing menggunakan pinset sambil berjalan dalam pembelajaran peningkatan keterampilan fisik-motorik pada anak usia 5-6 tahun kelompok B di salah satu Pos PAUD Kemuning Kota Cimahi, menghasilkan dampak yang positif. Hal ini dapat diketahui dari peningkatan kemampuan dalam permainan yang diperoleh pada kegiatan tindakan siklus I dan siklus II.

Kegiatan belajar-mengajar melalui pendekatan permainan kancing dimaksudkan untuk mengembangkan dan meningkatkan keterampilan fisik- 
motorik, sejalan dengan model pembelajaran inovasi anak usia dini: belajar seraya bermain dan bermain sambil belajar yang keduanya mengacu pada pembelajaran yang bermakna, kreatif, demokratis dan menyenangkan anak, salah satu model pembelajaran yang disebut PAIKEM (Pembelajaran Aktif, Inovatif, Kreatif, dan Menyenangkan). (Isjoni, H.. 2014)

Permainan kancing mengajarkan dan melatih anak kearah kemandirian, melatih kontrol diri dan koordinasi gerakan, mengajarkan membedakan warna-warna yang ada, juga dapat mengajarkan anak untuk membedakan ukuran (Hainstock, 1999)

Permainan kancing mempunyai banyak manfaat untuk peningkatan keterampilan fisik motorik, diantaranya adalah sarana melenturkan otot-otot (motorik halus dan motorik kasar). Keterampilan motorik halus disini adalah keterampilan yang melibatkan suatu gerakan yang diatur secara halus. Keterampilan motorik halus dapat mengembangkan kemampuan pada anak untuk menggunakan jari-jemarinya, secara khusus adalah ibu jari dan telunjuk. Kemampuan ini dapat ditingkatkan melalui kegiatan menggenggam, memegang, menjimpit dan merobek. Sedangkan keterampilan motorik kasar yang dimaksud disini adalah suatu kemampuan yang membutuhkan koordinasi sebagian besar anggota tubuh anak, yang melibatkan aktivitas otot tangan, kaki dan seluruh tubuh anak yang menggantungkan atau mengandalkan pada kematangan dalam koordinasi, aktivitas ini memerlukan tenaga yang cukup besar karena dilakukan oleh otot-otot yang lebih besar, selain itu juga memerlukan koordinasi kelompok otot-otot anggota tubuh tertentu yaitu otot-otot kaki yang dapat membuat mereka dapat melakukan gerakan meloncat, naik tangga atau memanjat pohon, berjalan dan berlari, mengendarai sepeda, berdiri pada satu kaki (kaki kanan ataupun kaki kiri), jungkir balik, bermain dengan sepatu roda.

Peningkatan keterampilan fisik motorik melalui permainan kancing berpengaruh terhadap beberapa aspek kehidupan anak. Diantaranya adalah:

1. Anak dapat menemukan hiburan yang nyata, sehingga jauh dari perasaan stres maupun hal lainnya yang dapat mengganggu kondisi psikologis mereka.

2. Anak dapat beranjak atau berpindah dari kondisi lemah ke kondisi kuat atau dari yang tidak berdaya menuju kondisi independen.

3. Anak dapat menyesuaikan diri atau beradaptasi dengan lingkungan khususnya sekolah.

4. Anak dapat mengembangkan kepribadiannya.

5. Mendorong anak bersikap mandiri dan berdikari sehingga dapat menyelesaikan persoalan yang dihadapi tanpa banyak bergantung atau mengandalkan bantuan dari orang lain.

Adapun unsur-unsur pokok dalam permainan keterampilan fisik-motorik adalah kekuatan, kecepatan, power, ketahanan, kelincahan, keseimbangan, fleksibilitas, dan koordinasi. (Decaprio. 2013.)

Hal-hal yang diukur atau dinilai dalam keterampilan fisik motorik anak usia dini adalah:

1. Gerak refleks, yaitu respons atau tanggapan motorik atau gerak cepat tanpa sadar yang muncul ketika para siswa mempraktikkan atau mengerjakan sesuatu.

2. Gerak dasar, gerakan yang terarah pada keterampilan kompleks yang khusus.

3. Gerak dasar fundamental atau dikenal dengan gerakan yang terjadi tanpa latihan namun dapat dibentuk atau diperhalus melalui praktik atau latihan yang terpola dan bisa ditebak. Secara umum dikelompokkan dalam 
tiga macam gerak, yaitu gerakan lokomotor, gerakan non lokomotor dan gerakan manipulatif.

4. Keterampilan perseptual, yaitu kemampuan dalam memahami atau mengerti dan menginterpretasikan atau menafsirkan informasi sebagai rangsangan yang datang dari dalam maupun luar tubuh (informasi sensor) atau kemampuan pengetahuan (kemampuan intelek) untuk mencari makna dari data atau informasi yang diterima oleh berbagai indra.

5. Keterampilan fisik, yaitu keterampilan motorik (kasar dan halus) yang menjadi kebutuhan di sekolah dan luar sekolah sebagai bekal dalam mengatasi tantangan ataupun rintangan, termasuk menyelesaikan berbagai persoalan.

6. Gerakan terampil (skilled movements), yakni gerakan yang memerlukan belajar, seperti keterampilan dalam olahraga.

7. Komunikasi nondiskusi (tanpa bahasa atau melalui gerakan), yang meliputi gerak interpretatif, yakni gerakan-gerakan tubuh yang dilakukan berdasarkan gerakan estetis dan kreatif. (Decaprio. 2017.)

Dari hasil wawancara yang dilakukan pada awal penelitian antara peneliti dan guru kelas serta observasi pra tindakan yang dilakukan di awal penelitian terhadap anak sebelum diterapkan permainan kancing pada anak usia 5-6 tahun di Kelompok B, ada anak yang tidak mau bergerak untuk mengikuti kegiatan, yang mengalami kesulitan memasukkan benda-benda kecil kedalam botol baik secara langsung ataupun dengan menggunakan alat, ada anak mengalami kesulitan memasukkan tali kedalam lubang (meronce), ada anak berjalan dan berlarinya kurang dapat terarah, sebagian lagi belum dapat menggunakan pensil dengan benar, masih nampak kesulitan dan kaku.
Permasalahan terjadi karena keterlibatan dan keingintahuan anak kurang aktif, anak-anak kurang merespon penyampaian guru, dan peneliti dalam menyampaikan kegiatan kurang maksimal, kurang membimbing dan memotivasi anak, penguatan atau penghargaan terhadap hasil karya juga belum diberikan dengan sepenuhnya.

Dari hasil observasi dan tes awal tersebut maka peneliti menyusun perencanaan sebagai upaya yang dapat dilakukan untuk meningkatkan keterampilan fisik-motorik anak usia 5-6 tahun di kelompok B melalui beberapa permainan kancing dengan memperhatikan kelemahan atau kekurangan pada saat observasi dan tes awal.

Sebelum penelitian dilaksanakan, peneliti melakukan koordinasi dengan guru yang mengajar kelas B di Pos PAUD dan sepakat bahwa penelitian tindakan dilakukan di kelas dan dilaksanakan pada dua siklus yang setiap siklusnya terdiri dari tiga pertemuan. Kemudian peneliti bersama guru kelas kelompok B merancang dan membuat rencana pembelajaran (RPPH) yang digunakan sebagai pedoman atau acuan dalam proses pelaksanaan penelitian tindakan kelas, masingmasing berisikan tujuan dan tema kegiatan bermain, menentukan aspek perkembangan/ peningkatan keterampilan serta indikator materi atau bahan observasi yang akan dilakukan oleh peneliti, menentukan metode atau ragam main, menentukan tempat/ruang yang digunakan atau dipakai dalam pembelajaran, bahan serta peralatan permainan dan urutan, aturan/tata cara permainan.

Pada pelaksanaan kegiatan bermain, peneliti bersama guru kelas melaksanakan tiga tahap, yaitu (1) kegiatan pra-bermain yaitu persiapan/ pengkondisian peserta didik, (2)kegiatan bermain/permainan, saat dilakukannya kegiatan permainan, 
penelitian/observasi dan penilaian, (3) kegiatan penutup yang berisi stimulus untuk menarik perhatian, menumbuhkan dan membangkitkan minat anak, menanamkamkan keingintahuan anak tentang aspek penting dalam permainan kancing, menghubungkan pengalaman anak pada saat melakukan permainan kancing, memahami seberapa dalam penghayatan anak ketika mengikuti atau melakukan kegiatan belajar-mengajar dan bermain bersama, belajar untuk berbagi kesempatan dan giliran dalam bermain. (Moeslichatoen. 2004)

Di awal setiap kegiatan belajarmengajar melalui permainan kancing ini peneliti menyampaikan kembali materi awal pembelajaran dan anak memperhatikan penjelasan peneliti tentang bagaimana melakukan permainan kancing satu persatu, mulai dari meronce, menjimpit dan memasukkan benang ke dalam lobang kancing, memasangkan kancing sesuai bentuk dan warnanya, menyambung pita, memasukkan kancing dalam botol sesuai warna sambil berlari, dan memindahkan kancing menggunakan pinset sambil berjalan.

Selama pembelajaran guru dan peneliti lebih intensif membimbing, memotivasi, membantu anak-anak yang mengalami kesulitan dan melakukan pendekatan pada anak agar hasil peningkatan yang diperoleh sesuai dengan harapan.

Setelah kegiatan atau proses pembelajaran berakhir, guru dan peneliti melakukan evaluasi sebagai bahan refleksi serta alat untuk mengetahui tingkat pencapaian perkembangan yang telah dicapai melalui permainan tersebut dan dapat digunakan juga sebagai pijakan untuk menentukan tindakan selanjutnya.

Keberhasilan peneliti pada proses pembelajaran melalui kegiatan permainan kancing (meronce, memasangkan kancing sesuai bentuk dan warnanya, menyambung pita, memasukkan kancing ke dalam botol sesuai warna sambil berlari, memindahkan kancing menggunakan pinset sambil berjalan), melalui pendekatan terhadap anak, membimbing dan memberi motivasi juga membuahkan hasil, memberi pujian dan apresiasi pada anak juga mulai dilakukan.

Faktor keberhasilan peningkatan keterampilan fisik-motorik anak melalui kegiatan permainan kancing (meronce, memasangkan kancing sesuai bentuk dan warnanya, menyambung pita, memasukkan kancing ke dalam botol sesuai warna sambil berlari, memindahkan kancing menggunakan pinset sambil berjalan) adalah adanya pengalaman yang dilakukan anak pada kegiatan Siklus I sehingga dalam kegiatan Siklus II kegiatan permainan kancing berjalan lancar.

Rata-rata dari hasil tindakan pada kegiatan Siklus I, Siklus II, kemampuan keterampilan fisik-motorik anak yang nampak dalam penelitian menunjukkan peningkatan.

\section{KESIMPULAN}

Berdasarkan dari hasil penelitian tindakan kelas yang telah dilakukan dalam siklus I, siklus II yang telah dijabarkan yaitu tentang peningkatan perkembangan keterampilan fisikmotorik anak usia 5-6 tahun di kelompok B melalui permainan kancing peneliti dapat menarik kesimpulan bahwa peningkatan perkembangan keterampilan fisik-motorik anak usia 5-6 tahun merupakan hal yang sangat perlu mendapat perhatian, karena hal tersebut adalah penunjang bagi semua kegiatan dan aktivitas atau pekerjaan yang dilakukan oleh anak sehari-hari.

Dari skor yang diperoleh pada setiap kegiatan/permainan kancing dalam kegiatan siklus I dan kegiatan siklus II terjadi peningkatan. 
Pada hasil evaluasi, observasi dan refleksi akhir, sebagian besar anak dalam beberapa jenis permainan kancing dapat menyelesaikan dengan baik tanpa kesulitan. Maka dengan demikian peneliti dapat mengambil kesimpulan bahwa permainan kancing dapat dilihat cukup efektif dalam peningkatan perkembangan keterampilan fisik motorik anak, karena dalam kegiatan permainan kancing ini melatih otot-otot kecil anggota tubuh seperti jari jemari, juga otot-otot besar atau kekuatan otot tangan dan kaki serta melatih koordinasi mata, tangan dan kaki.

\section{DAFTAR PUSTAKA}

Decaprio, Richard. 2013. Aplikasi Teori Pembelajaran Motorik di Sekolah. Yogyakarta: DIVA Press.

Decaprio, Richard. 2017. Panduan

Mengembangkan Kecerdasan

Motorik Siswa. Yogyakarta: DIVA

Press

Fadlillah, M.. 2016. Edutainment

Pendidikan Anak Usia Dini. Jakarta:

Prenadamedia Group.

Hainstock, Elizabeth G.. 1999. Metode

Pengajaran Montessori untuk Anak

Pra-Sekolah. Jakarta: Pustaka

Delapratasa.

Isjoni, H.. 2014. Model Pembelajaran

Anak Usia Dini. Bandung: Penerbit

Alfabeta.

Mutiah, Diana. 2010. Psikologi

Bermain Anak Usia Dini. Jakarta:

Prenadamedia Group.

R., Moeslichatoen. 2004. Metode

Pengajaran di Taman Kanak-

Kanak. Jakarta: Rineka Cipta.

Heris, H. 2014. Panduan Bagi Guru

Penelitian Tindakan Kelas Suatu

Karya Tulis Ilmiah. Bandung:Refika

Aditama 


\section{JURNAL GERIA}

ISSN : 2614-6347 (Print) 2714-4107 (Online)

Vol.1 | No.5 | September 2018 